\title{
The Layos Granite, Hercynian Complex of Toledo (Spain): an example of parautochthonous restite-rich granite in a granulitic area
}

\author{
L. Barbero and C. Villaseca
}

\begin{abstract}
The Layos Granite forms elongated massifs within the Toledo Complex of central Spain. It is late-tectonic with respect to the F2 regional phase and simultaneous with the metamorphic peak of the region, which reached a maximum temperature of $800-850^{\circ} \mathrm{C}$ and pressures of $400-600 \mathrm{MPa}$. Field studies indicate that this intrusion belongs to the "regional migmatite terrane granite" type. This granite is typically interlayered with sill-like veins and elongated bodies of cordierite/garnet-bearing leucogranites. Enclaves are widespread and comprise restitic types (quartz lumps, biotite, cordierite and sillimanite-rich enclaves) and refractory metamorphic country-rocks including orthogneisses, amphibolites, quartzites, conglomerates and calc-silicate rocks.

These granites vary from quartz-rich tonalites to melamonzogranites and define a S-type trend on a QAP plot. Cordierite and biotite are the mafic phases of the rocks. The particularly high percentage of cordierite $(10 \%-30 \%)$ varies inversely with the silica content. Sillimanite is a common accessory mineral, always included in cordierite, suggesting a restitic origin. The mineral chemistry of the Layos Granite is similar to that of the leucogranites and country-rock peraluminous granulites (kinzigites), indicating a close approach to equilibrium. The uniform composition of plagioclase $\left(\mathrm{An}_{25}\right)$, the high albitic content of the $\mathrm{K}$-feldspar, the continuous variation in the $\mathrm{Fe} / \mathrm{Mg}$ ratios of the mafic minerals, and the high $\mathrm{Ti}$ content of the biotites $(2 \cdot 5-6 \cdot 5 \%)$ suggest a genetic relationship.

Geochemically, the Layos Granite is strongly peraluminous. Normative corundum lies between $4 \%$ and $10 \%$ and varies inversely with increase in $\mathrm{SiO}_{2}$. The $\mathrm{CaO}$ content is typically low $(<1.25 \%)$ and shows little variation; similarly the LILE show a limited range. On many variation diagrams, linear trends from peraluminous granulites to the Layos Granite and associated leucogranite can be observed. The chemical characteristics argue against an igneous fractionation or fusion mechanism for the diversification of the Layos Granite. A restite unmixing model between a granulitic pole (represented by the granulites of the Toledo Complex) and a minimum melt (leucogranites) could explain the main chemical variation of the Layos Granite. Melting of a pelitic protolith under anhydrous conditions (biotite dehydration melting) could lead to minimum-temperature melt compositions and a strongly peraluminous residuum.

For the most mafic granites $\left(61-63 \% \mathrm{SiO}_{2}\right)$, it is estimated that the trapped restite component must have been around $65 \%$. This high proportion of restite is close to the estimated rheological critical melt fraction, but field evidence suggests that this critical value has been exceeded. This high restite component implies high viscosity of the melt which, together with the anhydrous assemblage of the Layos Granite and the associated leucogranites, indicates $\mathrm{H}_{2} \mathrm{O}$-undersaturated melting conditions. Under such conditions, the high viscosity magma (crystal-liquid mush) had a restricted movement capacity, leading to the development of parautochthonous plutonic bodies.
\end{abstract}

KEY WORDS: cordierite-rich granites, dry-melting, Iberian Variscan belt, restite-unmixing, source materials, strongly peraluminous.

The Complejo Plutono-Migmatítico de Toledo, hereafter termed the Toledo Complex, forms an E-W elongated block of high-grade metamorphic and plutonic rocks to the $\mathrm{S}$ of Toledo in central Spain. It is part of the Centro-Iberian zone of the axial zone of the Hercynian Belt (Julivert et al. 1974). To the $\mathrm{N}$, the Toledo Complex is overlain by post-Mesozoic sedimentary deposits and to the $\mathrm{S}$ it is bounded by a major listric fault which brings it into contact with low-grade Palaeozoic sediments in which was emplaced a post-tectonic epizonal batholith (Fig. 1).

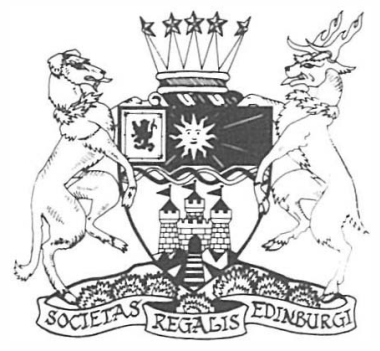

The Toledo Complex comprises a metamorphic assemblage of presumed pre-Ordovician age, consisting mainly of metapelites with some orthogneisses and minor metapsammites and marbles. The metamorphism has granulitic facies characteristics and is assumed to be Hercynian in age. The granulite terrane exhumation is explained by extensional thinning developed by great listric faults giving rise to a core-complex geometry (Casquet et al. 1988). Emplaced in the metamorphic rocks is a syntectonic felsic to mafic suite of igneous rocks (Barbero et al. 1990) 


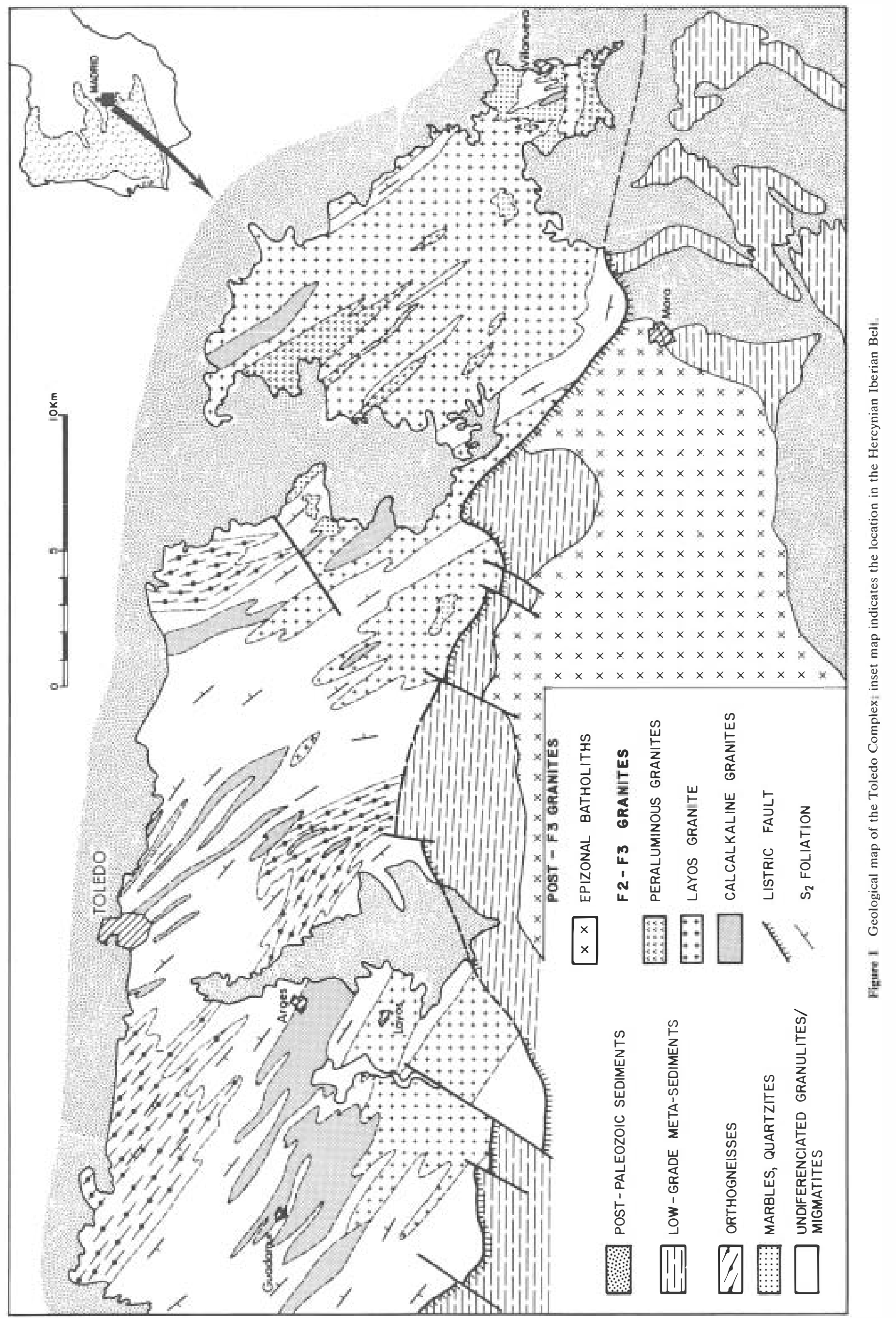


which was contemporaneous with or slightly earlier than bodies of heterogeneous strongly peraluminous parautochthonous granites.

This paper deals with petrographical, mineralogical, geochemical and genetic aspects of one of the most peraluminous of these granites, the Layos Granite.

\section{Geological setting}

The main structure of the Toledo Complex is a strain-slip foliation (S2) with $110^{\circ}-170^{\circ}$ regional strike, usually dipping to the E. This foliation is seen in the metamorphic rocks, mainly in the nonpelitic types (orthogneisses, psammitic paragneisses). In the pelitic varieties, the migmatisation event has erased the S2 foliation and has generated granoblastic non-foliated rocks with a marked banded structure coherent with the S2 foliation of the orthogneisses and metapsammites. In general, the $\mathrm{F} 1$ tectonic phase is almost completely obliterated and only some sporadic folds surrounded by S2 and axial F1 surfaces affected by S2 can be observed (Martín Escorza \& López Martínez 1978). The F3 tectonic phase causes large- to small-scale asymmetric folds with axial surfaces near-vertical and parallel to the S2 foliation. A weak mineral elongation lineation is sporadically developed, but S3 axial surface foliations are not common. There are two later tectonic phases that cause rotation and folding of the pre-existent structures (Martín Escorza \& López Martínez 1978).

The metamorphic rocks of the Toledo Complex are of both sedimentary and igneous origin. The main metaigneous types are leucocratic gneisses and augen gneisses. These rocks are similar to those of the Spanish Central System, probably of late-Cambrian or early-Ordovician age (Vialette et al. 1987; Wildberg et al. 1989). These metaigneous rocks are exposed mainly in the northern part of the complex (Fig. 1). They retain a foliated structure and because of their low mica content are poorly migmatised.

The metasedimentary types include peraluminous granulites (kinzigitic in affinity), biotitic gneisses, quartzites, amphibolites, marbles and conglomerates, the first being the most abundant type. The granulites exhibit a strong migmatitic layering which defines a stromatic structure characterised by a cordierite-rich mesosome (with Qtz + $\mathrm{Kfs}+\mathrm{Pl}+\mathrm{Crd}+\mathrm{Bt}+\mathrm{Grt}+\mathrm{Sp}+\mathrm{Sil} \pm \mathrm{Ilm}$ ) which alternates with narrow leucosomes (Fig. 2(A)), varying from garnet- to cordierite-, and to a lesser extent biotite-, bearing leucogranites. Especially noteworthy is the presence of large rounded garnet crystals in the leucosomes that mainly consist of $\mathrm{Qtz}+\mathrm{Kfs} \pm \mathrm{Pl}$ (Fig. 2(A)). In general, it is difficult to find melanosomes or mafic rims around the
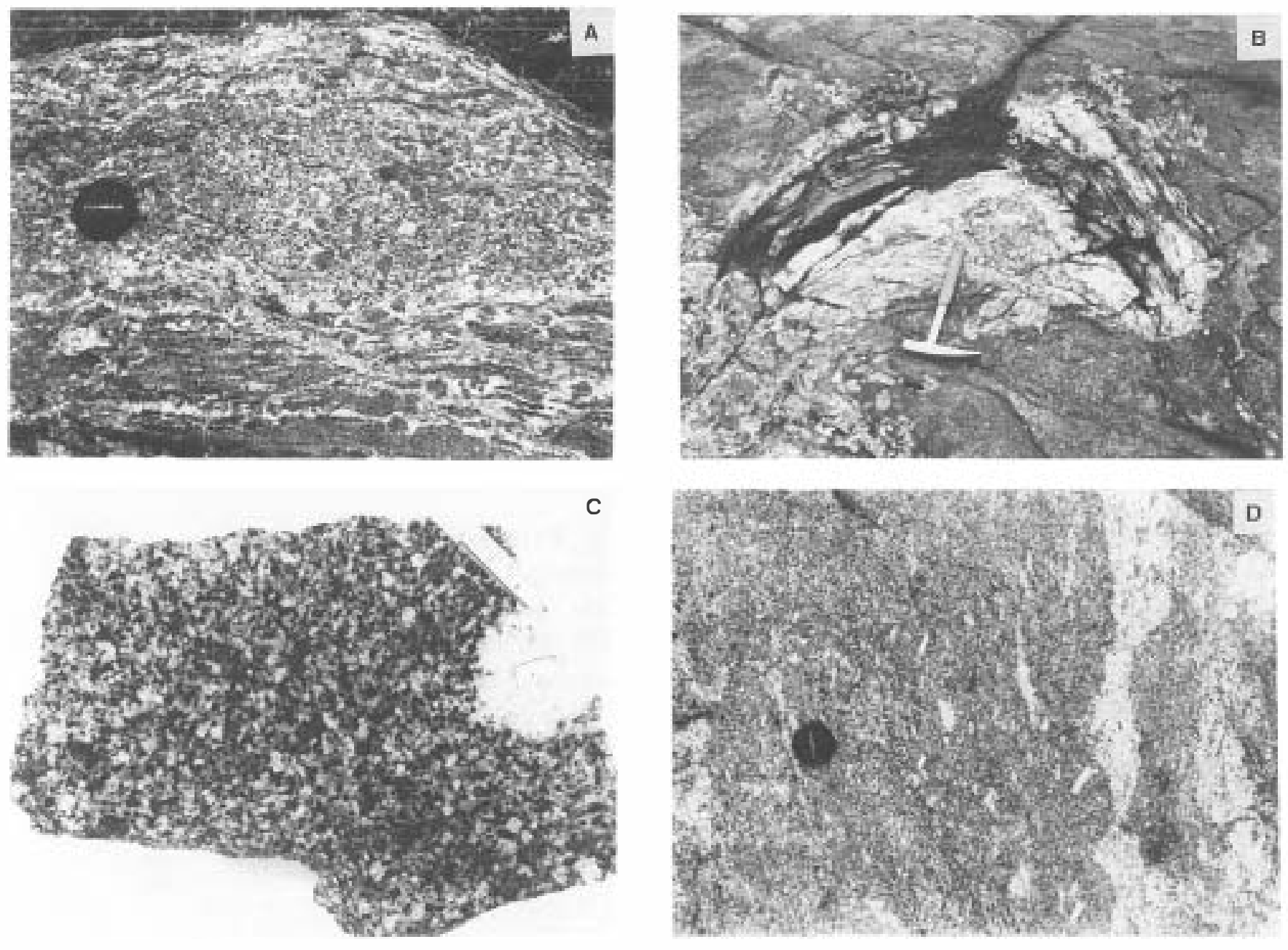

Figure 2 (A) General aspect of the peraluminous migmatitic granulites, showing the stromatic structure marked by the garnet-bearing leucosomes and the cordierite-rich dark mesosome. (B) Partially migmatised enclave of folded metamorphic country rock enclosed in the Layos Granite. (C) Hand-sample aspect of the cordierite-rich Layos Granite; a K-feldspar lump is also shown. (D) Field aspect of the Layos Granite in which it is possible to observe some $\mathrm{K}$-feldspar phenocrysts and also a vein-like associated peraluminous leucogranite. 
leucosomes. Sometimes the stromatic structure of the rock is disrupted, leading to diatexitic rocks with similar appearance to the Layos Granite.

Marbles, calc-silicate rocks and quartzites are abundant in the eastern part of the Toledo Complex (Fig. 1). Elsewhere these rocks appear as layers boudinaged and occasionally disrupted in the migmatitic pelites.

Two groups of igneous rocks may be distinguished, namely calcalkine granites and associated mafic rocks, and peraluminous granites (Fig. 1). Both were emplaced relatively late with respect to the second deformational phase; they sometimes show intrusive features and locally cut the S2 foliation. In places it is possible to observe enclaves with early F3 folds enclosed in the granites (Fig. 2(B)). Nevertheless, all the granites show local development of foliation and phenocryst alignment with the S2 direction, and in some places these structures are folded by the third phase (F3). Thus the age of emplacement of these granites must be close to the second tectonic phase, probably between $\mathrm{F} 2$ and F3.

The calcalkaline granites and associated mafic rocks comprise three different suites which have been studied by Barbero et al. (1990). The first consists of olivine-pyroxene gabbros that outcrop as isolated sills, enclaves and small massifs within the calcalkaline granites. The second consists of amphibole gabbros that are always associated with the intermediate and felsic granites; locally it is possible to observe mingling processes between them. The third suite comprises intermediate-felsic granites, with variable porphyritic texture, in which are typically found microgranular tonalitic enclaves (Barbero et al. 1990).

The peraluminous granites form two groups based on the content of normative corundum. Moderately peraluminous granites (normative corundum $\leq 4 \%$ ) consist of the Moncloa type, a K-feldspar megacryst-bearing porphyritic granodiorite; the Villanueva type, a garnet-bearing microporphyritic granite; and the Fuente-Topino type, a biotitic leucogranite with cordierite aggregates. Strongly peraluminous granites (normative corundum $>4 \%$ ) are structurally and lithologically heterogeneous and rich in xenoliths and restitic components. To this group belongs the cordierite-bearing Layos Granite which is commonly associated with peraluminous leucogranites, resembling the vein-like types of migmatite leucosomes.

\section{Metamorphic grade}

The coexistence of the assemblage $\mathrm{Grt}+\mathrm{Crd}+\mathrm{Sil}+\mathrm{Bt}+$ $\mathrm{Sp}+\mathrm{Kfs}$ in pelitic rocks, together with the presence of orthopyroxene in metamorphic coronas around olivine in the gabbros (Barbero \& Villaseca 1988) are indicative of granulite facies. The extensive migmatisation and anatexis observed in the pelitic rocks is also consistent with high-grade metamorphic conditions. The coexistence of garnet, biotite and cordierite indicates low-pressure conditions (Green \& Ringwood 1967); this is consistent with the absence of garnet in the coronitic gabbros.

The results of several calculations using different mineral equilibria in the peraluminous granulites, biotitic gneisses and metabasites are summarised in Table 1. A maximum pressure limit has been estimated with the GRIPS barometer (Bohlen \& Liotta 1986; Ghent \& Stout 1984) of around $700 \mathrm{MPa}$ for temperatures near $800^{\circ} \mathrm{C}$. The garnet-biotite, cordierite-biotite and spinel-cordierite thermometers yield temperatures between 720 and $870^{\circ} \mathrm{C}$. To avoid closure problems with the $\mathrm{Fe}-\mathrm{Mg}$ interchange thermometers (Frost \& Chacko 1989) we have estimated the cross-over of the GASP barometer with other $P-T$ dependent equilibria (e.g. spinel-cordierite). This crossover indicates temperatures between 770 and $820^{\circ} \mathrm{C}$, in agreement with the other temperature estimates, and pressures of 500-600 MPa, clearly under the GRIPS limit.

The formation of cordierite by garnet destabilisation (coronas of cordierite around garnet are frequent in these granulites), gives pressures $50-150 \mathrm{MPa}$ lower than the estimated metamorphic peak conditions, suggesting an isothermal decompression process in the area. This is very frequent in migmatitic Variscan terranes (Ibarguchi \& Martínez 1982; Jones \& Brown 1990). Temperature estimates in the metamorphic assemblages of the metabasites, based on Opx-Cpx and Opx-Bt thermometers (Table 1 ), give values between $770-950^{\circ} \mathrm{C}$, confirming the granulitic character of the area. In summary, the metamorphic peak conditions of the Toledo Complex are within the range of $800 \pm 50^{\circ} \mathrm{C}$ and $500 \pm 100 \mathrm{MPa}$, clearly in the granulite facies. Under these conditions, biotite breakdown and subsequent dehydration melting reactions can occur; thus the development of granulite facies paragenesis and partial melting are concomitant processes. This coincidence is not fortuitous as in regions which are inferred to have yielded significant quantities of granitic melts by fluid-absent partial fusion, temperature estimates are always restricted to this range of $800-850^{\circ} \mathrm{C}$, indicating either a buffering effect and/or the inability of geothermometers to record higher temperatures (Vielzeuf et al. 1990).

\section{Petrography and mineralogy of the Layos Granite}

The Layos Granite has a distinctive dark colour (Fig. 2(C)) due to the high proportion of cordierite, reaching $30 \%$ in

Table 1 Peak metamorphic temperatures $\left({ }^{\circ} \mathrm{C}\right)$ and pressure $(\mathrm{MPa})$ estimates from various calibrations

\begin{tabular}{|c|c|c|c|c|c|c|c|c|c|c|c|}
\hline \multirow[b]{3}{*}{ Sample } & \multirow[b]{3}{*}{ Type } & \multicolumn{7}{|c|}{ Temperature } & \multicolumn{3}{|c|}{ Pressure } \\
\hline & & \multicolumn{2}{|c|}{ Grt-Bt } & \multicolumn{2}{|c|}{ Grt-Crd } & \multirow[t]{2}{*}{$\mathrm{Sp}-\mathrm{Crd}$} & \multirow[t]{2}{*}{ Opx-Cpx } & \multirow[t]{2}{*}{$\mathrm{Opx}-\mathrm{Bt}$} & \multirow[t]{2}{*}{ GASP } & \multirow{2}{*}{$\mathrm{Sp}-\mathrm{Crd}$} & \multirow[t]{2}{*}{ Grt-Crd } \\
\hline & & $\mathrm{T} 1$ & $\mathrm{~T} 2$ & $\mathrm{~T} 3$ & $\mathrm{~T} 4$ & & & & & & \\
\hline 87085 & Granulite & 826 & 841 & 827 & 797 & 868 & & & & & \\
\hline $\mathrm{T}-356$ & Granulite & 807 & 821 & 793 & 762 & 751 & & & 540 & 610 & 400 \\
\hline 90961 & Granulite & 774 & 785 & 829 & 799 & 839 & & & 560 & 590 & 420 \\
\hline $\mathrm{T}-361$ & Gneiss & 743 & 757 & 722 & 690 & 768 & & & 620 & 560 & 540 \\
\hline 89083 & Gabbro & & & & & & 903 & 951 & & & \\
\hline 89081 & Gabbro & & & & & & 837 & & & & \\
\hline 87075 & Gabbro & & & & & & & 772 & & & \\
\hline
\end{tabular}

Notes: All temperature and pressure estimates are based on averaged garnet core, and biotite or cordierite from matrix. Garnet-biotite thermometers are: T1 = Ferry \& Spear (1978), T2 = Hodges \& Spear (1982); garnet-cordierite thermometers are: T3 = Holdaway \& Lee (1977), T4 = Lavrenteva \& Perchuck (1981); spinel-cordierite thermometry after Vielzeuf (1983); orthopyroxene-clinopyroxene thermometry after Wells (1977); orthopyroxene-biotite thermometry after Sengupta et al. (1990); GASP barometer is calculated at $800^{\circ} \mathrm{C}$ following the method of Ganguly \& Saxena (1984); spinel-cordierite barometry after Vielzeuf (1983); garnet-cordierite barometer of Holdaway \& Lee (1977). 
the most mafic rocks, with a mean value of $20 \%$. Petrographically it varies from quartz-rich tonalites to melamonzogranites, with granodiorites being the most abundant type. On a QAP plot (Fig. 3) it defines a typical S-type distribution. In places it is possible to observe porphyritic varieties characterised by K-feldspar phenocrysts aligned in $120^{\circ}-140^{\circ}$ directions; locally a gradual transition between porphyritic and non-porphyritic types can be observed. The Layos Granite is little deformed and only a weak mineral elongation or compositional banding is locally observed.

This granite is closely related to peraluminous leucogranites that occur as veins or dyke-like bodies within it, and locally define a banded aspect to the granite (Fig. 2(D)). It is also possible to find synplutonic emplacement processes with other strongly peraluminous varieties, which are indicated by the occurrence of imbrication zones following F3 directions. In these zones the interdigitation processes can produce mingled facies between the Layos Granite and the coeval peraluminous granite.

A major characteristic of the Layos Granite is the abundance of enclaves, which comprise three groups. The first group consists of refractory metamorphic country rock enclaves corresponding to the types already described: orthogneisses, amphibolites, quartzitic conglomerates, calcsilicate rocks and marbles. These enclaves are the most abundant and can reach a maximum size of 2-3 $\mathrm{m}$, although usually they are not greater than $20-25 \mathrm{~cm}$ in size (Fig. 2(B)).

The second group consists of restitic enclaves which are, in decreasing order of abundance:

(a) Quartz lumps ranging in size from $1-2 \mathrm{~cm}$ up to $50 \mathrm{~cm}$. In some of the larger lumps there is a gneissic partial rim around the quartz, suggesting a derivation from vein quartz in the original metamorphic sequence.

(b) Biotite-bearing enclaves usually $1-2 \mathrm{~cm}$ in size and rounded in form. They commonly present biotite-bearing layers alternating with cordierite-sillimanite- and minor spinel-bearing layers, resembling the regional peraluminous granulites.

(c) Cordierite-rich enclaves $(1-2 \mathrm{~cm})$ generally formed with intergrowths of cordierite and quartz. Minor biotite and sillimanite are locally present.

(d) Sillimanite-rich enclaves of rounded shape and up to

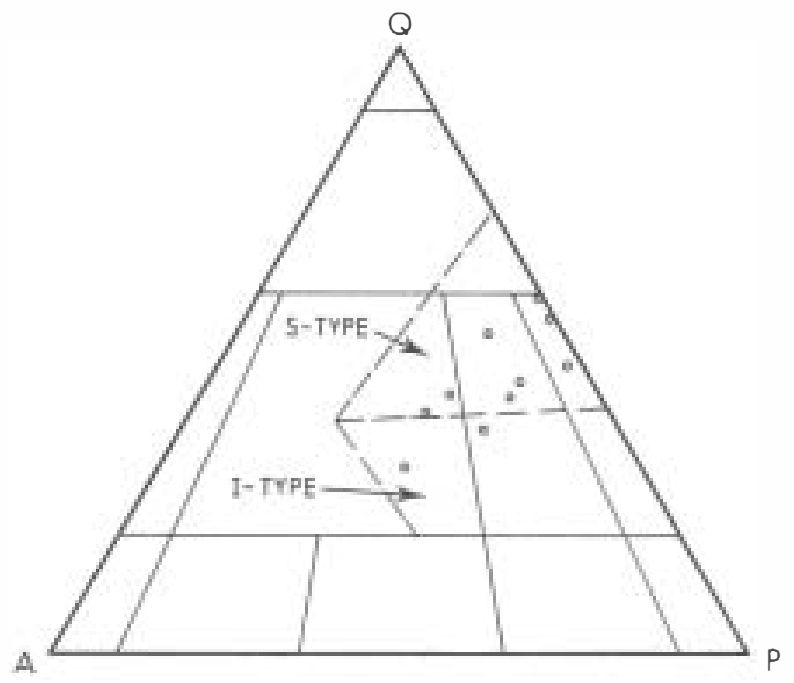

Figure 3 QAP (Streckeisen 1976) plot for selected samples of the Layos Granite; S- and I-type fields after Bowden et al. (1984).
$25 \mathrm{~cm}$ in diameter. The aluminosilicate is sometimes included in cordierite or plagioclase crystals with minor biotite, K-feldspar, spinel and quartz.

(e) K-feldspar lumps showing corroded borders and perthitic textures that are locally associated with quartz, forming micro-pegmatitic textures. It is possible to find inclusions of quartz, plagioclase, and minor biotite and sillimanite within these crystals. Exceptionally, they can reach up to $25 \mathrm{~cm}$ in diameter, but generally they are $3-4 \mathrm{~cm}$ in size. They are occasionally surrounded by a biotite rim (Fig. 2(C)).

The third group consists of mafic igneous enclaves. These enclaves are very scarce and can be found in places where mafic rocks outcrop (Villanueva region, see Fig. 1) and it seems likely that they were incorporated at the emplacement level. Amphibole-biotite-bearing quartz diorites and gabbros are the main types. Scarce microgranular enclaves with quartz, plagioclase, biotite and accessory garnet are also present.

The Layos Granite is a medium-grained rock with a hypidiomorphic texture. Occasionally it shows a porphyritic texture defined by euhedral K-feldspar phenocrysts. The major minerals are quartz, plagioclase, $\mathrm{K}$-feldspar, cordierite and biotite. Accessory minerals include apatite, zircon, monazite, tourmaline, sillimanite, garnet, ilmenite $\left(\operatorname{Ilm}_{98}\right)$, rutile and iron sulphides. Selected mineral compositions are given in Table 2 .

Plagioclase composition ranges between $\mathrm{An}_{25}-\mathrm{An}_{23}$. In some samples there is a narrow rim with more albitic composition $\left(\mathrm{An}_{12}-\mathrm{An}_{5}\right)$. Particularly remarkable is the absence of zoning (variations greater than $3 \%$ in An are not observed). Thus, neither calcic cores nor more complex and marked zoning are found, in contrast to the other peraluminous or calc-alkaline allochthonous granites (e.g. Rottura et al. 1990; Chappell et al. 1987). It is noteworthy that the plagioclase has the same composition over the range from tonalites to monzogranites and is also similar to that of the peraluminous granulites and leucogranites (Fig. 4(A)).

$\mathrm{K}$-feldspar compositions vary between $\mathrm{Or}_{92}$ and $\mathrm{Or}_{71}$. Occasionally the K-feldspar crystals display some perthitic veins. Sporadically, sillimanite needles, biotite, plagioclase and quartz are included in these crystals. Like the plagioclase, the K-feldspar of the Layos Granites and those of the peraluminous granulites and leucogranites have similar compositions. The relatively high albitic component of the K-feldspar resembles that obtained for minimumtemperature melts and partially fused pelitic xenoliths (Grapes 1985).

The most abundant ferromagnesian phase is cordierite. This mineral usually occurs as euhedral or subhedral grains, with frequent inclusions of acicular sillimanite, biotite and quartz, suggesting a restitic origin for this mineral (Chappell et al. 1987). The $\mathrm{Fe} /(\mathrm{Fe}+\mathrm{Mg})$ ratios vary from $0 \cdot 38-0 \cdot 48$; they are close to the ratios displayed by the cordierites of the peraluminous granulites $(0 \cdot 38-0.53)$ and leucogranites $(0 \cdot 44-0.62)$. The very low $\mathrm{Na}+\mathrm{K}+\mathrm{Ca}$ contents of these cordierites are characteristic of granulite facies cordierites (Vry et al. 1990). According to those authors, the low $\mathrm{Na}+\mathrm{K}+\mathrm{Ca}$ values imply relatively high $\mathrm{X}_{\mathrm{CO}_{2}}$ in the cordierite $(0 \cdot 3-0 \cdot 7)$. Figure 4 is a $\mathrm{Mn}$ vs $\mathrm{Na}+\mathrm{K}+\mathrm{Ca}$ plot on which it is clear that the cordierites of the Layos Granite are $\mathrm{Mn}$-, $\mathrm{Ca}$ - and alkali-poor compared to those of the typical peraluminous Hercynian Iberian batholiths (Casillas 1989; Rottura et al. 1989; Andonaegui 1990).

Biotite occurs as subhedral crystals with a typical interstitial character (Andonaegui 1990). The relatively high $\mathrm{Ti}$ and low $\mathrm{Al}^{\mathrm{VI}}$ contents are typical of granulite facies biotites (Dymek 1983). These high $\mathrm{Ti}$ and $\mathrm{Al}^{\mathrm{VI}}$ values 
Table 2 Representative microprobe analyses of mineral phases of the Layos Granite

\begin{tabular}{|c|c|c|c|c|c|c|c|c|}
\hline & PI & Kfs & Bt-1 & $\mathrm{Bt}-2$ & Crd-1 & Crd-2 & Grt & Ilm \\
\hline $\mathrm{SiO}_{2}$ & $62 \cdot 51$ & $65 \cdot 15$ & $34 \cdot 48$ & 34.93 & $48 \cdot 69$ & $48 \cdot 08$ & $37 \cdot 41$ & $0 \cdot 01$ \\
\hline $\mathrm{TiO}_{2}$ & 0.00 & $0 \cdot 01$ & $5 \cdot 12$ & $3 \cdot 11$ & 0.00 & 0.00 & $0 \cdot 05$ & $54 \cdot 19$ \\
\hline $\mathrm{Al}_{2} \mathrm{O}_{3}$ & $23 \cdot 18$ & $18 \cdot 88$ & $16 \cdot 84$ & $18 \cdot 18$ & 31.49 & $31 \cdot 41$ & $20 \cdot 28$ & 0.04 \\
\hline $\mathrm{FeO}^{*}$ & $0 \cdot 10$ & & $19 \cdot 58$ & $19 \cdot 82$ & $9 \cdot 13$ & $10 \cdot 32$ & $32 \cdot 37$ & $45 \cdot 78$ \\
\hline $\mathrm{Cr}_{2} \mathrm{O}_{3}$ & & & $0 \cdot 12$ & 0.00 & $0 \cdot 00$ & $0 \cdot 01$ & $0 \cdot 04$ & $0 \cdot 01$ \\
\hline $\mathrm{MnO}$ & & & & $0 \cdot 08$ & $0 \cdot 27$ & $0 \cdot 23$ & $2 \cdot 50$ & $1 \cdot 80$ \\
\hline $\mathrm{MgO}$ & & & $7 \cdot 84$ & $8 \cdot 15$ & $6 \cdot 74$ & $6 \cdot 68$ & $4 \cdot 22$ & $0 \cdot 18$ \\
\hline $\mathrm{CaO}$ & $4 \cdot 94$ & 0.05 & $0 \cdot 04$ & $0 \cdot 02$ & $0 \cdot 01$ & $0 \cdot 00$ & 0.73 & $0 \cdot 00$ \\
\hline $\mathrm{Na}_{2} \mathrm{O}$ & $8 \cdot 86$ & 1.96 & $0 \cdot 17$ & $0 \cdot 08$ & $0 \cdot 18$ & $0 \cdot 20$ & & \\
\hline $\mathrm{K}_{2} \mathrm{O}$ & $0 \cdot 26$ & 13.69 & $9 \cdot 08$ & 8.99 & $0 \cdot 02$ & 0.02 & & \\
\hline Total & $99 \cdot 85$ & $99 \cdot 74$ & $93 \cdot 27$ & $93 \cdot 36$ & $96 \cdot 53$ & $96 \cdot 95$ & $97 \cdot 60$ & $102 \cdot 01$ \\
\hline Oxygen & 32 & 32 & 22 & 22 & 18 & 18 & 12 & 3 \\
\hline $\mathrm{Si}$ & $11 \cdot 11$ & 11.95 & $5 \cdot 39$ & $5 \cdot 44$ & $5 \cdot 12$ & $5 \cdot 07$ & $6 \cdot 11$ & 0.00 \\
\hline $\mathrm{Al}(\mathrm{IV})$ & $4 \cdot 85$ & $4 \cdot 08$ & $2 \cdot 61$ & $2 \cdot 56$ & & & 0.00 & \\
\hline $\mathrm{Al}(\mathrm{VI})$ & & & $0 \cdot 50$ & $0 \cdot 78$ & 3.90 & $3 \cdot 90$ & $3 \cdot 90$ & \\
\hline $\mathrm{Fe}$ & $0 \cdot 01$ & $0 \cdot 00$ & $2 \cdot 56$ & $2 \cdot 58$ & $0 \cdot 80$ & $0 \cdot 91$ & $4 \cdot 42$ & $0 \cdot 96$ \\
\hline $\mathrm{Ti}$ & & & $0 \cdot 40$ & $0 \cdot 36$ & $0 \cdot 00$ & $0 \cdot 00$ & 0.01 & $1 \cdot 01$ \\
\hline $\mathrm{Mn}$ & & & & & $0 \cdot 02$ & 0.02 & $0 \cdot 35$ & $0 \cdot 04$ \\
\hline $\mathrm{Mg}$ & & & $1 \cdot 83$ & 1.89 & $1 \cdot 06$ & $1 \cdot 05$ & $1 \cdot 03$ & 0.01 \\
\hline $\mathrm{Ca}$ & $0 \cdot 94$ & $0 \cdot 01$ & $0 \cdot 01$ & $0 \cdot 00$ & $0 \cdot 00$ & $0 \cdot 00$ & $0 \cdot 13$ & \\
\hline $\mathrm{Na}$ & 3.05 & $0 \cdot 70$ & 0.05 & 0.02 & $0 \cdot 04$ & $0 \cdot 04$ & & \\
\hline K & $0 \cdot 06$ & $3 \cdot 21$ & $1 \cdot 81$ & $1 \cdot 78$ & $0 \cdot 00$ & $0 \cdot 00$ & & \\
\hline
\end{tabular}

Notes: $\mathrm{Pl}=$ plagioclase, $\mathrm{Kfs}=\mathrm{K}$-feldspar; $\mathrm{Bt}=$ biotite $\mathrm{Crd}=$ cordierite $; \mathrm{Grt}=$ garnet $; \mathrm{Ilm}=$ ilmenite .

contrast with the lower values displayed by the biotites of other Variscan peraluminous granites (Fig. 4(C)) (cordierite-bearing granites; Casillas 1989; Andonaegui 1990; Rottura et al. 1989). The biotites of the Layos Granite have $\mathrm{Fe} /(\mathrm{Fe}+\mathrm{Mg})$ ratios very similar to those of the peraluminous granulites, although there is a narrow variation range. This fact suggests a possible restitic origin for this mineral.

Finally, the accessory garnet $\left(\mathrm{Alm}_{75} \mathrm{Py}_{17} \mathrm{Sp}_{6} \mathrm{Gr}_{2}\right)$ is very low in the spessartine molecule compared to other peraluminous monzogranite-granodiorite plutons (Villaseca $\&$ Barbero in press). Similarly, ilmenites are also Mn-poor $(\leq 2.3 \%)$ and contrast with the main granitic plutons of the area (Andonaegui 1990; Brandebourger 1984; Casillas 1989), or with the S-type granites (Whalen \& Chappell 1988).

In summary, the feldspar and ferromagnesian phases are compositionally different from those of the main peraluminous Hercynian batholiths of the area and from other cordierite-bearing granites (Flood \& Shaw 1975; Speer 1981), and define an exotic granitic mineralogical assemblage.

\section{Geochemistry of the Layos Granite}

Major elements were determined by ICP spectrometry. Trace elements were analysed by XRF spectrometry using the method described by Brändle and Cerqueira (1972). Rare-earth elements were analysed by CNRS (Nancy, France) by ICP spectrometry. Seventeen samples of the Layos Granite from quartz-rich tonalites to monzogranites, six peraluminous granulites and five leucocratic rocks have been analysed. A further 13 analyses of Layos Granite and associated leucogranites are available from Andonaegui (1990). From these 41 analyses we have made a selection of the most significant rock compositions as given in Table 3 .

The Layos Granite ranges in $\mathrm{SiO}_{2}$ content from $61-72 \%$. Most of the samples are clearly richer in modal quartz than the normal granitic series (Fig. 3). The granite is strongly peraluminous with normative corundum values ranging from
$4-10 \%$, the mean value being $7 \%$. Normative corundum varies inversely with the silica content. This strongly peraluminous character is also shown on the A-B diagram (Debon \& Le Fort 1983), where the Layos Granite defines a strongly positive trend with high A values (Fig. 5); this feature is not very common in other granitic series, and only occurs in some S-type granites (White \& Chappell 1987) and some restite-rich types (Clarke \& Lyons 1986). On the A-B diagram the most mafic varieties of the Layos Granite plot close to the peraluminous granulites and in the field of pelitic sediment composition (Fig. 5). The felsic members of the Layos Granite trend towards the leucogranitic field. The strongly peraluminous character is in marked contrast with the less peraluminous Iberian Hercynian cordierite-bearing batholiths (normative corundum $\leq 3 \%$ ). Furthermore, these allochthonous and post-tectonic plutons show an opposite trend of increase in the peraluminous index with silica content.

The major elements of the Layos Granite show two noteworthy characteristics: firstly, the high $\mathrm{Fe}, \mathrm{Mg}$ and $\mathrm{Ti}$ contents (in some cases $\mathrm{FeO}_{1}+\mathrm{MgO}+\mathrm{TiO}_{2}>10 \%$ ) reflect the high modal abundance of cordierite and biotite; secondly, the very low variation in the $\mathrm{CaO}$ content which precludes igneous fractionation processes involving plagioclase. This limited $\mathrm{CaO}$ variation in the Layos Granite is in the same range as in the peraluminous granulites and leucogranites (Fig. 6), and is in accord with the similar plagioclase composition in the three lithological groups.

Similar limited variation, as silica increases, is shown by other major elements and especially the alkalis (Fig. 6). Nevertheless, on Harker Diagrams, the Layos Granite displays linear trends which suggest either mixing between contrasting end-members, or unmixing of some intermediate types into more mafic and felsic end-members. Trace element data display more complex trends (Fig. 6) with generally greater scatter. Nevertheless, some of them show more or less defined ranges of variation. For example, $\mathrm{Ba}$, $\mathrm{Rb}, \mathrm{Sr}$ and $\mathrm{Cr}$ tend to decrease with increasing silica content. The high $\mathrm{Cr}-\mathrm{Ni}$ content of these granites is controlled by the different proportion of ferromagnesian phases rich in these elements (i.e. biotite, cordierite). 
REE patterns of the Layos Granite are characterised by a negative Eu anomaly (Fig. 7); the different samples have similar LREE and more variable HREE patterns $\left(\mathrm{Gd}_{\mathrm{N}} / \mathrm{Lu}_{\mathrm{N}}=0 \cdot 8-36\right)$ than those of the peraluminous granulites. The associated leucogranites have either as much REE as the metasediments or less total REE contents

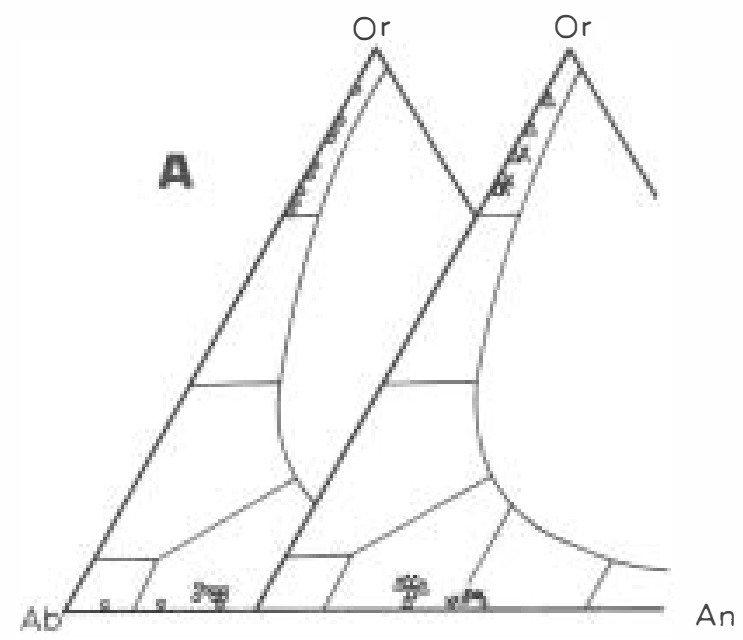

B

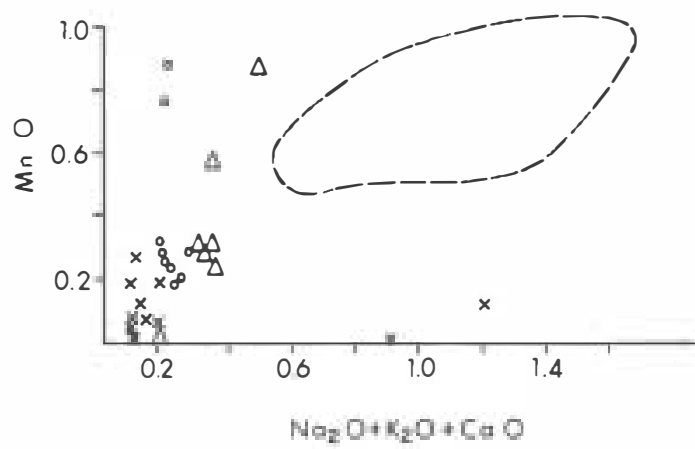

$\times$ PERALUMINOUS GRANULITES

- LAYOS GRANITES

$\triangle$ LEUCOGRANITES

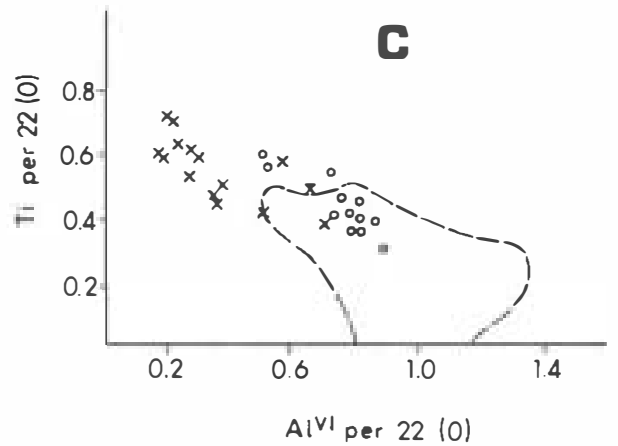

Figure 4 (A) Feldspar compositions on the $\mathrm{Or}-\mathrm{Ab}-\mathrm{An}$ molecular diagram. (B) Cordierite composition on a $\mathrm{MnO}$ vs $\mathrm{Na}_{2} \mathrm{O}+\mathrm{K}_{2} \mathrm{O}+$ $\mathrm{CaO}$ plot; dashed field corresponds to cordierites of typical peraluminous Hercynian batholiths. (C) Biotite composition in terms of $\mathrm{Ti}$ and $\mathrm{Al}^{\mathrm{VI}}$ contents; dashed field corresponds to biotites of typical peraluminous Hercynian batholiths (see text for explanation). (particularly HREE), with different patterns. The sample with the lowest total REE and the most marked positive Eu anomaly is characteristic of some minimum-temperature granite compositions typical of disequilibrium melting processes in relatively anhydrous environments (Moller \& Muecke 1984; Barbey et al. 1989) or possibly is the consequence of some crystal accumulation of feldspars (Sawyer 1987).

\section{Granite petrogenesis}

\subsection{Main evolutionary mechanism}

The Layos Granite is a catazonal pluton and a regional-migmatite terrane granite. Its anatectic origin is confirmed by: its parautochthonous character indicated by the absence of a contact aureole in the adjacent metamorphic rocks; the thermodynamical equilibrium between its mineral assemblages and those of the country rock granulites; and the close relationships between the age of emplacement and the migmatisation event.

On many Harker Diagrams the variation trend of the Layos Granite is clearly linear and lies between the compositional fields of granulites and leucogranites (Figs 5, 6). A crystal fractionation process seems to be unlikely
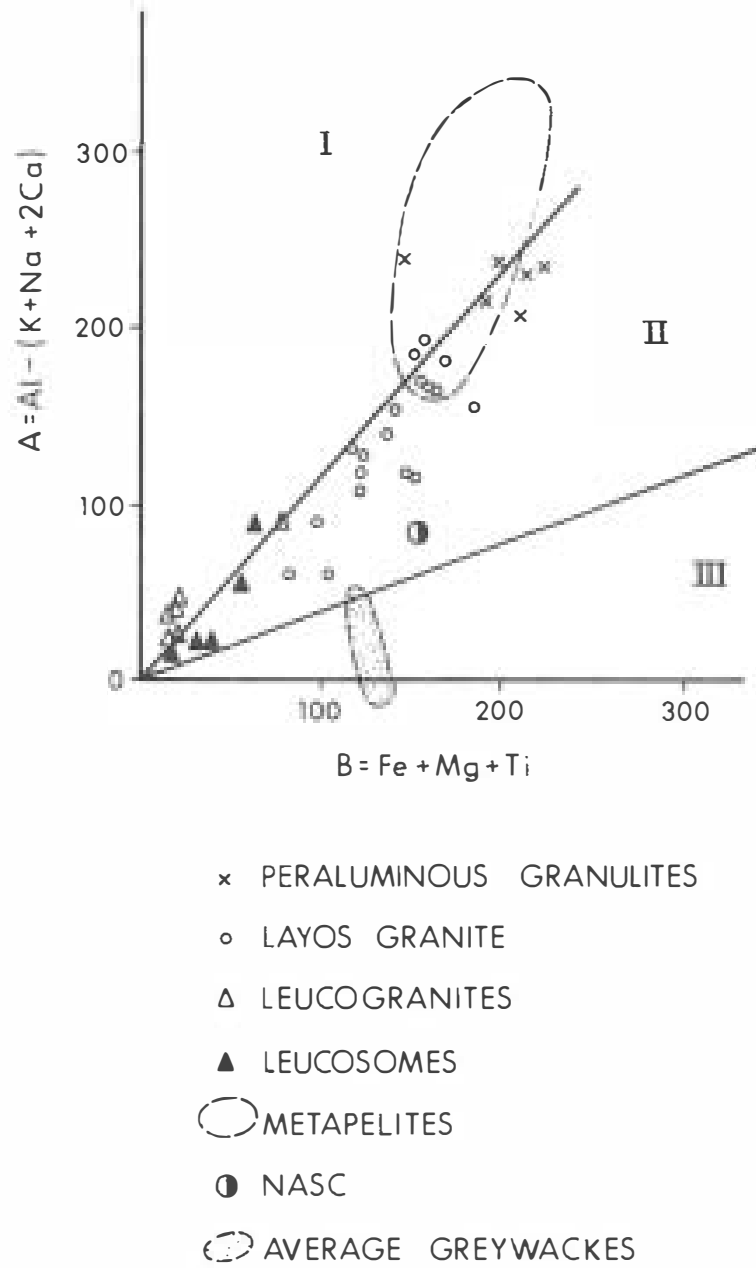

Figure 5 Plot of the peraluminous granulites, Layos Granite and leucogranites in the A-B diagram after Debon \& Le Fort (1983); composition fields of metapelites of the Spanish Central System (Villaseca 1983), average greywackes (McRae \& Nesbitt 1980) and North Amerian Shale Composite (NASC of Gromet et al. 1984) are also reported (see text for explanation); Field $\mathrm{I}=$ muscovite > biotite granites; Field II = muscovite \pm biotite granites; Field III = muscovite $<$ biotite granites. 
Table 3 Major, trace element and corundum normative contents of representative pelitic granulites (1 to 3), Layos Granites (4 to 11 ) and associated leucogranites (12 to 15); sample 15 is from Andonaegui (1990); sample 12 corresponds to a leucosome band

\begin{tabular}{|c|c|c|c|c|c|c|c|c|c|c|c|c|c|c|c|}
\hline & 1 & 2 & 3 & 4 & 5 & 6 & 7 & 8 & 9 & 10 & 11 & 12 & 13 & 14 & 15 \\
\hline Sample & 90961 & $\mathrm{~T}-383$ & $\mathrm{~T}-388$ & 89103 & 90537 & 91085 & 90538 & 90966 & 90964 & 90968 & 89861 & T-382 & 90959 & $\mathrm{~T}-400$ & 81925 \\
\hline $\mathrm{SiO}_{2}$ & $56 \cdot 96$ & $57 \cdot 15$ & $58 \cdot 19$ & $61 \cdot 37$ & $63 \cdot 20$ & $64 \cdot 61$ & $66 \cdot 07$ & $68 \cdot 78$ & $69 \cdot 82$ & $71 \cdot 14$ & $72 \cdot 52$ & $69 \cdot 50$ & $72 \cdot 50$ & $74 \cdot 18$ & $74 \cdot 36$ \\
\hline $\mathrm{TiO}_{2}$ & $1 \cdot 12$ & $1 \cdot 13$ & $1 \cdot 12$ & $0 \cdot 61$ & $0 \cdot 70$ & $0 \cdot 82$ & $0 \cdot 81$ & 0.96 & 0.53 & 0.64 & $0 \cdot 66$ & $0 \cdot 52$ & $0 \cdot 26$ & $0 \cdot 13$ & $0 \cdot 06$ \\
\hline $\mathrm{Al}_{2} \mathrm{O}_{3}$ & $20 \cdot 10$ & $20 \cdot 16$ & $19 \cdot 43$ & $18 \cdot 45$ & $17 \cdot 88$ & $15 \cdot 52$ & $17 \cdot 03$ & $13 \cdot 63$ & $14 \cdot 49$ & 13.44 & $12 \cdot 30$ & $14 \cdot 96$ & $14 \cdot 81$ & $13 \cdot 78$ & $14 \cdot 40$ \\
\hline $\mathrm{Fe}_{2} \mathrm{O}_{3}$ & $3 \cdot 11$ & ${ }^{*} 9.39$ & *8.89 & $1 \cdot 01$ & $0 \cdot 19$ & $1 \cdot 74$ & $0 \cdot 64$ & ${ }^{*} 6 \cdot 20$ & $1 \cdot 26$ & $* 5.40$ & $0 \cdot 00$ & ${ }^{*} 2.56$ & $0 \cdot 15$ & ${ }^{*} 0 \cdot 81$ & $0 \cdot 37$ \\
\hline $\mathrm{FeO}$ & $6 \cdot 55$ & & & $5 \cdot 49$ & $5 \cdot 79$ & $3 \cdot 59$ & $5 \cdot 26$ & & $2 \cdot 47$ & & $5 \cdot 12$ & & $0 \cdot 88$ & & 0.75 \\
\hline $\mathrm{MgO}$ & $3 \cdot 66$ & $3 \cdot 39$ & $3 \cdot 40$ & $2 \cdot 67$ & $2 \cdot 38$ & $1 \cdot 90$ & $2 \cdot 17$ & $1 \cdot 70$ & $1 \cdot 28$ & $1 \cdot 32$ & $0 \cdot 29$ & $0 \cdot 25$ & 0.40 & & \\
\hline $\mathrm{MnO}$ & $0 \cdot 08$ & $0 \cdot 08$ & $0 \cdot 08$ & $0 \cdot 25$ & $0 \cdot 07$ & $0 \cdot 08$ & $0 \cdot 07$ & $0 \cdot 06$ & 0.06 & $0 \cdot 01$ & $0 \cdot 00$ & $0 \cdot 01$ & $0 \cdot 05$ & & \\
\hline $\mathrm{CaO}$ & 1.45 & $1 \cdot 54$ & $1 \cdot 52$ & 0.81 & $1 \cdot 22$ & $1 \cdot 25$ & 1.09 & $0 \cdot 76$ & 0.99 & 1.02 & $1 \cdot 01$ & $1 \cdot 25$ & $1 \cdot 13$ & & \\
\hline $\mathrm{Na}_{2} \mathrm{O}$ & $1 \cdot 75$ & $1 \cdot 79$ & $1 \cdot 82$ & $2 \cdot 01$ & $2 \cdot 01$ & $2 \cdot 61$ & $2 \cdot 32$ & $2 \cdot 27$ & $2 \cdot 71$ & $2 \cdot 66$ & $3 \cdot 65$ & $3 \cdot 25$ & $3 \cdot 21$ & & \\
\hline $\mathrm{K}_{2} \mathrm{O}$ & $2 \cdot 63$ & $3 \cdot 90$ & $3 \cdot 65$ & 4.03 & $4 \cdot 27$ & $3 \cdot 29$ & $3 \cdot 81$ & $3 \cdot 65$ & $4 \cdot 72$ & $2 \cdot 77$ & 2.77 & $7 \cdot 00$ & $5 \cdot 22$ & $5 \cdot 34$ & $4 \cdot 21$ \\
\hline $\mathrm{P}_{2} \mathrm{O}_{5}$ & $0 \cdot 20$ & $0 \cdot 13$ & $0 \cdot 14$ & $0 \cdot 23$ & 0.52 & $0 \cdot 35$ & $0 \cdot 23$ & $0 \cdot 16$ & $0 \cdot 33$ & $0 \cdot 19$ & $0 \cdot 36$ & $0 \cdot 34$ & $0 \cdot 28$ & $0 \cdot 16$ & $0 \cdot 22$ \\
\hline $\mathrm{H}_{2} \mathrm{O}$ & $1 \cdot 31$ & 1.06 & 1.42 & $2 \cdot 20$ & 1.42 & $2 \cdot 35$ & $1 \cdot 27$ & $1 \cdot 51$ & $1 \cdot 69$ & 1.46 & $1 \cdot 10$ & $1 \cdot 16$ & 0.57 & $0 \cdot 64$ & $0 \cdot 82$ \\
\hline Total & $98 \cdot 92$ & $99 \cdot 72$ & $99 \cdot 66$ & $99 \cdot 13$ & $99 \cdot 65$ & $98 \cdot 11$ & $100 \cdot 77$ & $99 \cdot 68$ & $100 \cdot 35$ & $99 \cdot 71$ & $99 \cdot 75$ & $99 \cdot 64$ & $99 \cdot 75$ & $99 \cdot 79$ & 99.98 \\
\hline $\mathrm{Ba}$ & 547 & 762 & 898 & 604 & 839 & 697 & 596 & 663 & 699 & 570 & 278 & 1174 & 848 & 573 & 614 \\
\hline $\mathrm{Cr}$ & 541 & 145 & 137 & 364 & 418 & 267 & 427 & 268 & 193 & 390 & 281 & 25 & 20 & 5 & 138 \\
\hline $\mathrm{Ni}$ & 80 & 57 & 54 & 65 & 45 & 43 & 45 & 38 & 23 & 50 & 37 & 10 & 5 & 5 & 41 \\
\hline $\mathrm{Rb}$ & 130 & 172 & 136 & 161 & 149 & 127 & 155 & 165 & 169 & 115 & 161 & 263 & 135 & 209 & 79 \\
\hline $\mathrm{Sr}$ & 187 & 243 & 256 & 173 & 202 & 193 & 192 & 130 & 235 & 151 & 114 & 261 & 197 & 155 & 208 \\
\hline Th & 16 & 19 & 23 & 16 & 12 & 21 & 7 & 15 & 13 & 9 & 8 & 22 & 12 & 12 & 1 \\
\hline Y & 35 & 27 & 25 & 23 & 38 & 48 & 25 & 23 & 28 & 18 & 10 & 8 & 9 & 5 & 11 \\
\hline $\mathrm{Zr}_{\mathrm{r}}$ & 173 & 218 & 219 & 123 & 195 & 296 & 190 & 309 & 207 & 213 & 198 & 166 & 133 & 71 & 87 \\
\hline $\mathrm{La}$ & $61 \cdot 6$ & $69 \cdot 4$ & $67 \cdot 4$ & $33 \cdot 5$ & & & $37 \cdot 6$ & $42 \cdot 9$ & $32 \cdot 2$ & $34 \cdot 0$ & $29 \cdot 9$ & $50 \cdot 0$ & $30 \cdot 8$ & $25 \cdot 2$ & \\
\hline $\mathrm{Ce}$ & $112 \cdot 6$ & $135 \cdot 7$ & $131 \cdot 8$ & $64 \cdot 5$ & & & $71 \cdot 4$ & $94 \cdot 2$ & $62 \cdot 9$ & $74 \cdot 7$ & $59 \cdot 8$ & $114 \cdot 6$ & $60 \cdot 9$ & $56 \cdot 0$ & \\
\hline Nd & $50 \cdot 9$ & $54 \cdot 8$ & $54 \cdot 2$ & $29 \cdot 1$ & & & 33.9 & $42 \cdot 3$ & $30 \cdot 0$ & $33 \cdot 3$ & $28 \cdot 2$ & $51 \cdot 3$ & $30 \cdot 1$ & $20 \cdot 3$ & \\
\hline $\mathrm{Sm}$ & $10 \cdot 3$ & $11 \cdot 0$ & $10 \cdot 98$ & $6 \cdot 5$ & & & $7 \cdot 5$ & 9.4 & $7 \cdot 1$ & $7 \cdot 6$ & $6 \cdot 2$ & 11.9 & $6 \cdot 3$ & $4 \cdot 0$ & \\
\hline $\mathrm{Eu}$ & $1 \cdot 76$ & 1.93 & $2 \cdot 09$ & $1 \cdot 25$ & & & $1 \cdot 36$ & 1.40 & $1 \cdot 37$ & 1.48 & $0 \cdot 90$ & 2.06 & $1 \cdot 62$ & $1 \cdot 01$ & \\
\hline $\mathrm{Gd}$ & $8 \cdot 23$ & 9.03 & $8 \cdot 24$ & 5.43 & & & $6 \cdot 40$ & $7 \cdot 81$ & $6 \cdot 64$ & $6 \cdot 77$ & 4.99 & $9 \cdot 65$ & $4 \cdot 68$ & $3 \cdot 32$ & \\
\hline Dy & 6.95 & $7 \cdot 07$ & $6 \cdot 37$ & $4 \cdot 54$ & & & $5 \cdot 55$ & $5 \cdot 82$ & $5 \cdot 11$ & 4.96 & $2 \cdot 94$ & 3.95 & $3 \cdot 95$ & 1.44 & \\
\hline Er & $3 \cdot 34$ & $3 \cdot 70$ & $3 \cdot 37$ & $3 \cdot 05$ & & & $3 \cdot 13$ & $3 \cdot 55$ & $2 \cdot 76$ & $2 \cdot 47$ & $1 \cdot 26$ & $1 \cdot 14$ & $1 \cdot 14$ & $0 \cdot 55$ & \\
\hline $\mathrm{Yb}$ & $3 \cdot 14$ & $3 \cdot 30$ & 3.03 & $4 \cdot 25$ & & & $3 \cdot 22$ & $3 \cdot 50$ & $3 \cdot 29$ & 1.99 & 0.97 & 0.51 & $0 \cdot 51$ & $0 \cdot 19$ & \\
\hline $\mathrm{Lu}$ & 0.52 & $0 \cdot 59$ & $0 \cdot 58$ & $0 \cdot 82$ & & & 0.54 & $0 \cdot 63$ & $0 \cdot 58$ & $0 \cdot 36$ & $0 \cdot 17$ & $0 \cdot 13$ & $0 \cdot 13$ & $0 \cdot 07$ & \\
\hline $\mathrm{C}$ & 11.97 & $11 \cdot 37$ & $12 \cdot 41$ & $9 \cdot 86$ & 8.98 & $6 \cdot 23$ & $7 \cdot 66$ & 5.94 & $3 \cdot 91$ & $6 \cdot 43$ & 3.93 & $4 \cdot 28$ & 1.99 & 0.93 & 3.03 \\
\hline
\end{tabular}

Notes: ${ }^{*}=$ total $\mathrm{Fe}$ as $\mathrm{Fe}_{2} \mathrm{O}_{3}$.

because of the absence of $\mathrm{CaO}$ variation and because an igneous granitic series could not evolve without plagioclase fractionation. However, in the most evolved rocks some porphyritic varieties locally display a gradual transition towards the much more abundant non-porphyritic types, possibly due to limited crystal fractionation. Other processes such as varying degrees of partial melting seem also to be unlikely. In such a fusion process a strong enrichment in incompatible elements and little variation in the compatible ones is to be expected (Minster \& Allègre 1977). On incompatible versus compatible element diagrams, the Layos Granite shows little variation for both types of elements, suggesting that a fusion mechanism cannot explain their chemical variability.

Some trace element concentrations in the Layos Granite are quite variable. $\mathrm{Zr}, \mathrm{P}$ and $\mathrm{Th}$ contents show the same variations as in the pelitic granulites, and are always higher than predicted from their solubility in granitic melts at temperatures in the range of this anatectic terrane (Watson 1987). This oversaturation in some HFS elements is better explained by inheritance of zircon, monazite and apatite in the major refractory phases and in the incongruent solids produced in the dehydration melting (biotite, cordierite, garnet, ...).

The REE contents of the Layos Granite show an inverse variation with silica increase, that is, the more restite-rich a granite, the higher the REE content. This fact again suggests that the accessory phases, which tend to be REE-rich, are mainly of restitic origin or are included in the solid melt residuum (Barbey et al. 1990). In general, the Layos Granite has total REE contents intermediate between those of the metapelites and leucogranites. The increase in the $\mathrm{La} / \mathrm{Lu}$ ratio of the leucogranites with respect to that of the peraluminous granulites and metapelites can be explained by the presence of residual garnet in these rocks, although some of that mineral was consumed in the cordierite-producing reactions.

In view of these observations, we strongly prefer a restite-unmixing process for the origin and diversification of the Layos Granite. In this restite-unmixing model the restitic pole will be represented by the peraluminous granulites, while the minimum-temperature melts correspond to the associated leucogranites.

\subsection{Nature of the source}

The most likely composition for the source rock would be that of a pelitic sediment. The normative corundum content $(>4 \%)$, increasing in the less felsic rocks, the low $\mathrm{Na} 2 \mathrm{O}$ $(\leq 3 \%)$ and $\mathrm{CaO}$ contents $(\leq 1.5 \%)$, and the LILE content of the Layos Granite $(\mathrm{Rb} \approx 100-170 \mathrm{ppm}, \mathrm{Sr} \approx 150-250 \mathrm{ppm}$ and $\mathrm{Ba} \approx 300-850 \mathrm{ppm}$ ), indicate a pelitic parent (Miller 1985). In several geochemical plots, the peraluminous granulites fall in the compositional fields of pelites. In Figure 5 we have plotted the variation field of pelitic metasediments of the Toledo Complex and the Spanish Central System, together with N American Shale Composite (NASC) (Gromet et al. 1984), and the mean values of some greywacke sediments (McRae \& Nesbitt 1980). It is clear that the peraluminous granulites plot in the pelitic field and far from the other sedimentary rock compositions. Furthermore, on chondrite-normalised spidergrams the Layos Granite and the granulites show similar patterns, with 
marked negative anomalies in $\mathrm{Nb}, \mathrm{Sr}, \mathrm{P}$ and $\mathrm{Ti}$ similar to other S-type granites and pelitic sediments (Thompson et al. 1984).

The other pole of the unmixing line corresponds to the leucogranites. We have sampled large leucogranitic massifs and also some leucosomes and little bands. There are some geochemical differences between the leucogranites of the large massifs and those of leucosomes, especially in $\mathrm{Na}_{2} \mathrm{O}$, $\mathrm{K}_{2} \mathrm{O}, \mathrm{Ba}, \mathrm{Rb}$ and $\mathrm{Sr}$ (Fig. 6). These differences are also evident in the $\mathrm{Qtz}-\mathrm{Ab}-\mathrm{Or}$ diagram in which the massif-type leucogranites plot close to the theoretical minimumtemperature melt composition in anhydrous conditions, being richer in the Or component than $\mathrm{H}_{2} \mathrm{O}$-saturated melts (Ebadi \& Johannes 1991). Some leucosomes are shifted from those thermal minimum compositions. Furthermore, the composition of the leucogranites is similar in major elements to that obtained by experimental melting of metapelitic protoliths (Wickham 1987a; Vielzeuf \& Holloway 1988; Patiño \& Johnston 1991).

The limited isotopic data on the Layos granodiorite and associated leucogranites (Andonaegui 1990, samples 81942,
81925 and 81926 of table III-6), clearly suggest a crustal source $\left({ }^{87} \mathrm{Sr} /{ }^{86} \mathrm{Sr} \geq 0 \cdot 713\right.$, Fig. 8$)$. The anatectic origin is more evident in the Layos Granite than in other peraluminous Hercynian granites (Del Moro 1987; Andonaegui 1990; Barbero et al. 1990; Rottura et al. 1990).

\subsection{Constraints on melt extraction and emplacement}

The available petrographical, mineralogical and geochemical data strongly suggest a restite-unmixing model for the formation of the Layos Granite. An estimate based on the linear patterns on variation diagrams indicates a maximum restitic component of about $65 \%$ for the most mafic rocks $\left(\mathrm{SiO}_{2} 61-63 \%\right)$, and about $25-30 \%$ for rocks with $67-68 \%$ $\mathrm{SiO}_{2}$. This high proportion of restite in the less evolved types is in good agreement with the observed modal proportion of restitic minera!s. Thus, the most mafic rocks have modal cordierite contents of around $30 \%$ and about $70 \%$ of the quartz may be restitic, although not easily identifiable as such (Chappell et al. 1987).

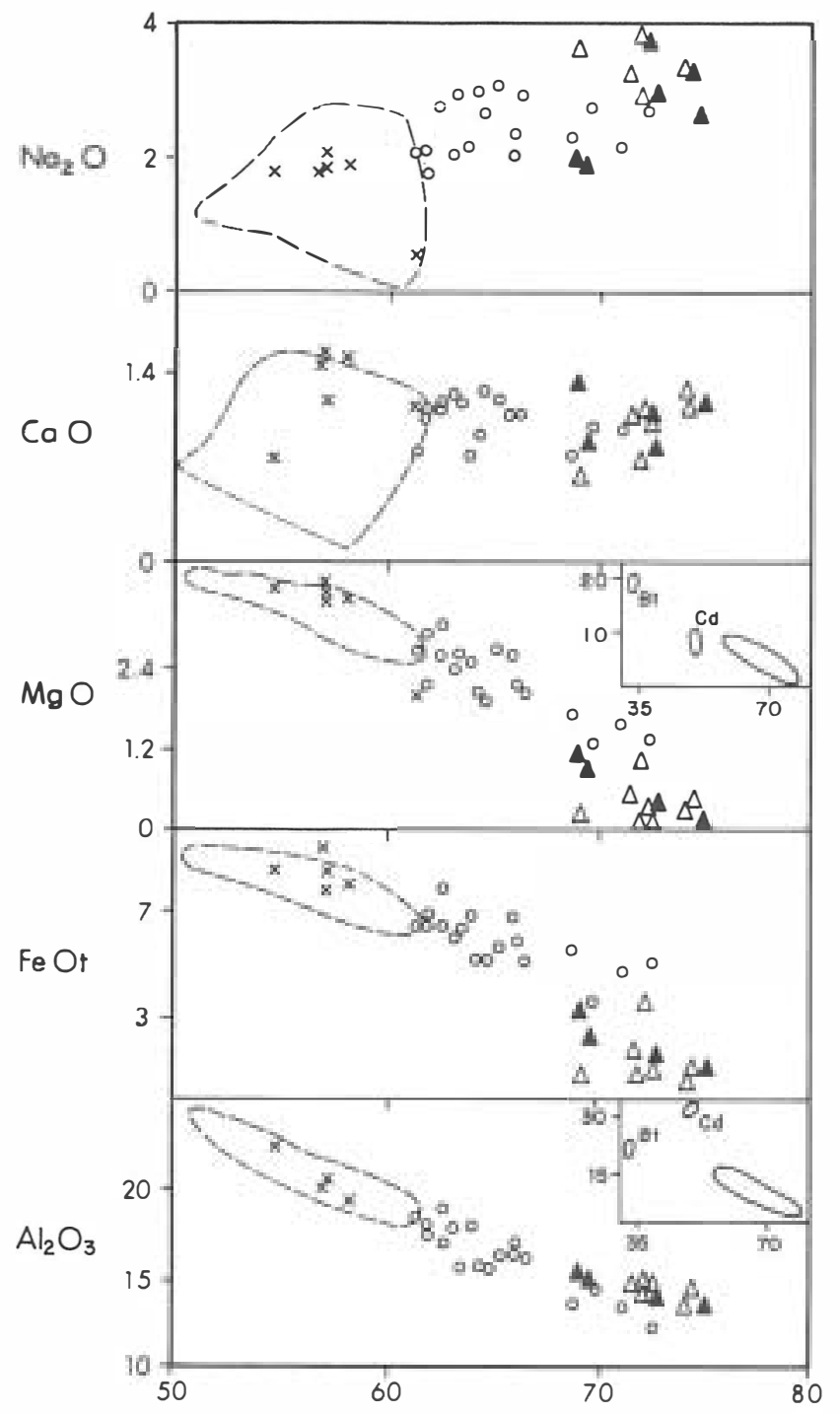

$\mathrm{SiO} \mathrm{O}_{2}$

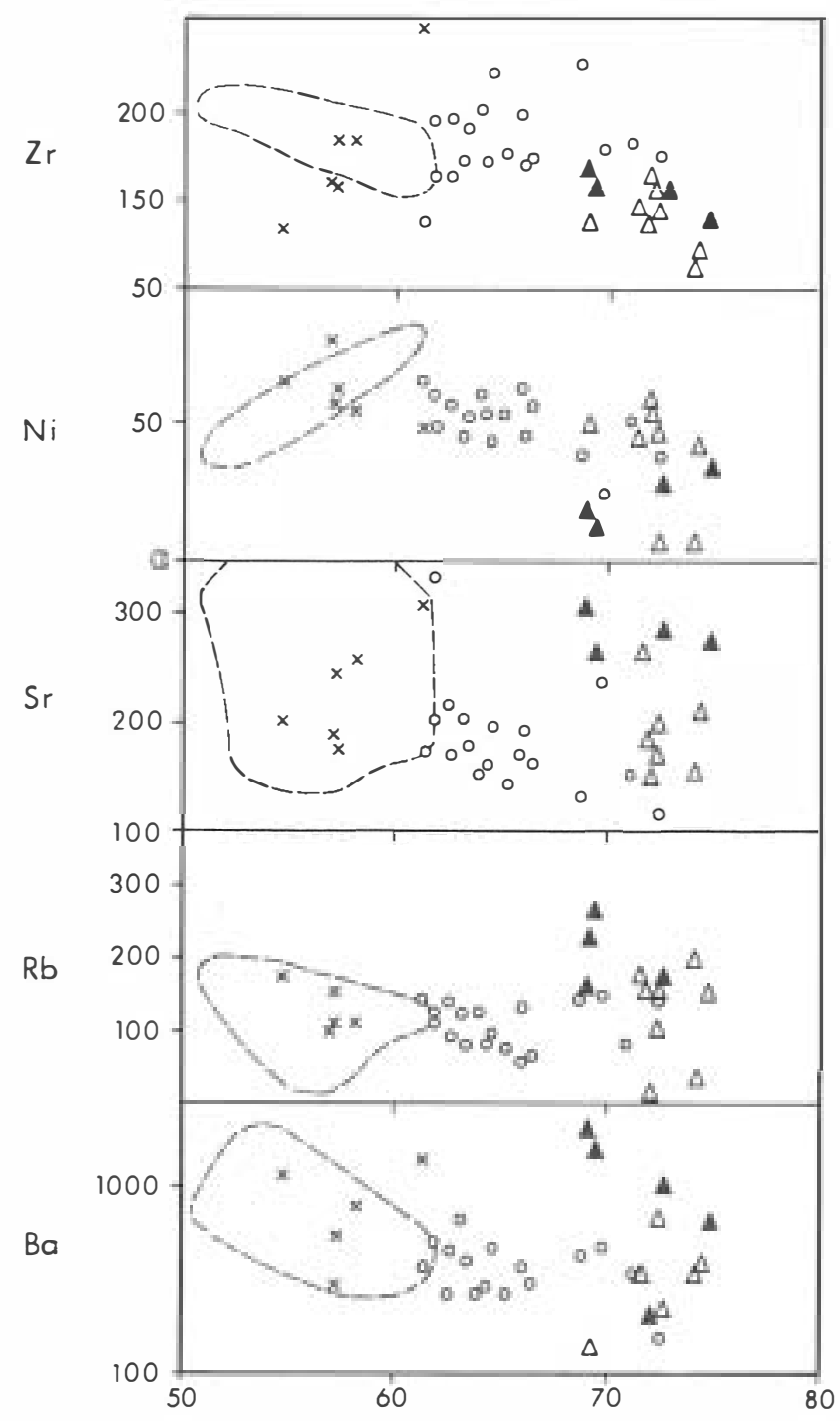

Si $\mathrm{O}_{2}$

Figure 6 Plots of granulites, Layos Granite and leucogranites in Harker Diagrams; in all diagrams dashed fields represent the compositional variation of the Sierra de Guadarrama metapelites; insets in $\mathrm{SiO}_{2}$ vs $\mathrm{Al}_{2} \mathrm{O}_{3}$ and $\mathrm{SiO}_{2}$ vs $\mathrm{MgO}$ diagrams represent the composition of the biotites and cordierites and the variation trend of the Layos Granite (see text for explanation); symbols as in Figure 5. 
All these data suggest a melt proportion of between $30 \%$ and $60 \%$, always higher than the rheological critical melt fraction. In high strain state conditions, as could be envisaged in the tectonometamorphic climax of the Toledo Complex, segregation would be possible even with as little as $25 \%$ high-viscosity $\mathrm{H}_{2} \mathrm{O}$-undersaturated felsic melt (Arzi 1978; Van der Molen \& Paterson 1979; Wickham 1987b; Miller et al. 1988).

Assuming that the metapelites contain about $25 \%$ biotite with $4 \% \mathrm{H}_{2} \mathrm{O}$ in the biotite and $\mathrm{X}_{\mathrm{w}}=0.41$ in the melt, at $800^{\circ} \mathrm{C}$ and $500 \mathrm{MPa}$ (see Le Breton \& Thompson 1988), the amount of melt produced could be around $35 \%$ in volume. This value is above the critical melt fraction, and would allow the segregation and accumulation of granitic magma. However, it seems likely that the Layos Granite was never fully melted and that restitic materials (biotite, cordierite, quartz, etc.) were redistributed by mechanical disaggregation due to convective overturn of large (cubic kilometresized) partially melted systems (Wickham 1987b). As a crystal-liquid mush, this anhydrous high-viscosity magma
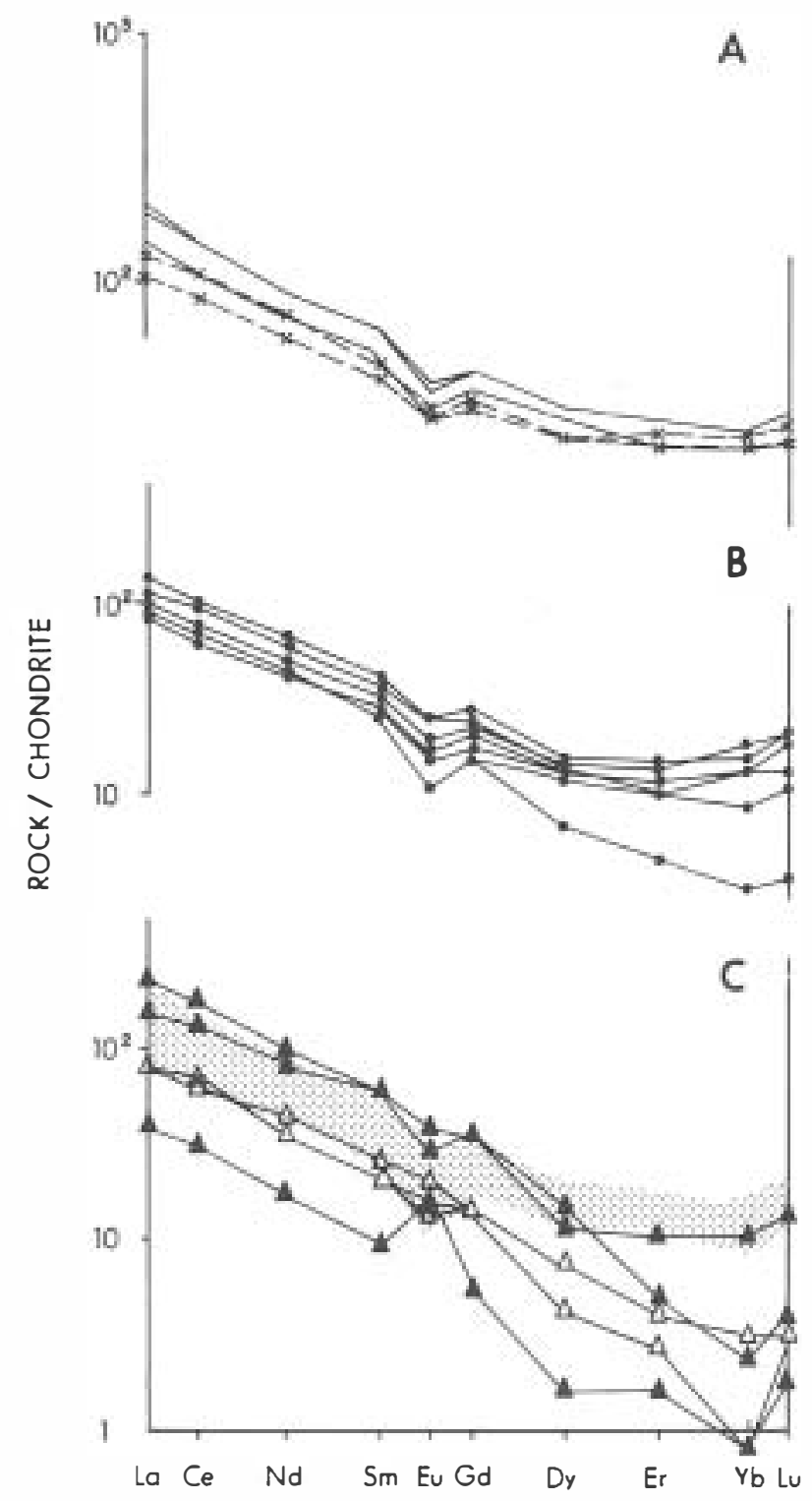

Figure 7 Chondrite-normalised (Masuda et al. 1973) REE patterns: (A) Peraluminous granulites (solid line) and metapelites (dashed line); (B) Layos Granite; (C) Leucogranites and leucosomes (solid triangles). The pelitic-granitic variation field (shaded area) is also shown. had a restricted movement capacity, giving rise to the aforementioned parautochthonous character (Fig. 9).

Other peraluminous magmas generated in this anatectic event contain a lower melt fraction, as represented by near minimum-temperature melt composition (Wickham 1987b). They could be synplutonically segregated as veins or dyke-like bodies within the Layos Granite, and generate a local complex-banded structure (Figs 2, 9).

\section{Conclusions}

The Toledo Complex consists of high-grade metamorphic rocks which were syntectonically intruded by a mafic-felsic calcalkaline association and by heterogeneous peraluminous granites to which the Layos Granite belongs.

The strongly peraluminous Layos Granite is characterised by a high modal proportion of cordierite and other restitic minerals. Its synchronous emplacement during the regional

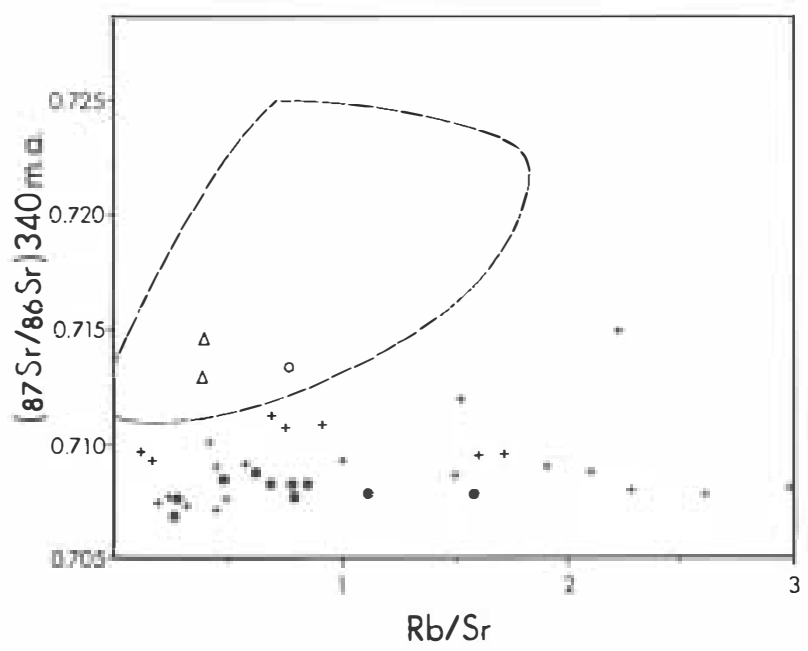

Figure $8 \mathrm{Rb} / \mathrm{Sr}$ vs $\left({ }^{87} \mathrm{Sr} /{ }^{86} \mathrm{Sr}\right)_{340}$ a plot showing the leucogranites $(n=2)$ and Layos Granite $(n=1)$; dashed field represents the variation of metapelites from several zones of the Hercynian belt (Ivrea, Strona and Calabria, Del Moro 1987); symbols: circle $=$ Layos granite; triangle $=$ leucogranites; dots $=$ Toledo Complex calcalkaline granites (Barbero et al. 1990); crosses = cordieritebearing Hercynian batholiths (Rottura et al. 1990; Andonaegui 1990); see text for explanation.
A

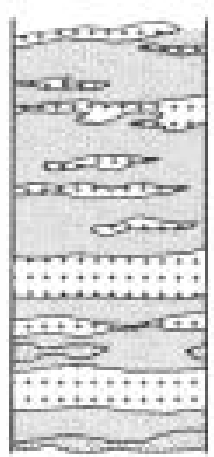

B

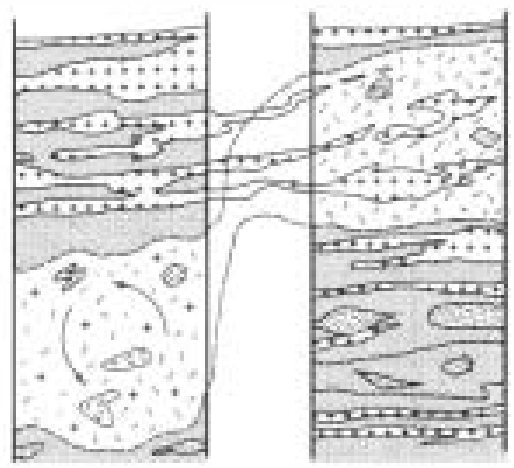

Figure 9 Schematic petrogenetic model for the generation and emplacement of the Layos Granite and associated leucogranites. (A) Development of wide migmatite zones in which pods of leucogranitic melts segregate. (B) The rheological critical melt fraction is exceeded and convective homogenisation occurs. (C) The resultant large volume of crystal-liquid mush segregates and with limited ascent within the crust develops syntectonic intrusions accompanied by segregation of leucogranitic bodies. 
metamorphic climax and its restite-rich character lead to unusual mineralogical features: plagioclase is almost unzoned and does not vary in composition from the mafic to the more felsic members of the series; K-feldspar has relatively high albitic content; cordierite has low alkali and Mn content and usually contains sillimanite inclusions; biotite has high $\mathrm{Ti}$ and low $\mathrm{Al}^{\mathrm{VI}}$ contents.

Geochemically the most remarkable characteristics are the high normative corundum values (as much as 10\%) increasing in the more mafic types and the very limited variation in $\mathrm{CaO}$ content in the whole series.

In the light of these features, the chemical variations observed in the Layos Granite can be best explained by a restite-unmixing process between an acid pole represented by the associated minimum-temperature melt leucogranites and a restite pole constituted by the peraluminous granulites that are spatially, chemically and mineralogically associated with the Layos Granite. The source material of the Layos Granite has the chemical and isotopic characteristics of a pelitic metasediment. The high proportion of restitic material in the Layos Granite confers a relatively restricted movement capacity, resulting in a parautochthonous emplacement of this crystal-liquid mush.

The Layos Granite has contrasted petrographical and geochemical features compared to the main cordieritebearing batholiths of the Iberian Variscan Belt. These monzogranitic batholiths usually define Gueret-type trends on an A-B plot, being more peraluminous in the more felsic varieties. We consider that this voluminous plutonism, late to post-tectonically emplaced in upper levels, has experienced considerable mobility within the crust and has to be derived from different source materials, probably more granodioritic in composition.

The scarcity of restite-rich granites such as the Layos Granite implies that dry melting of pelitic protoliths is not the usual mechanism of melt generation in this part of the Iberian Hercynian Belt.

\section{Acknowledgements}

We are especially grateful to Norman Snelling for his constructive critical review and for the revision of the English version of the text. We wish also to acknowledge the contributions of Alexandro Rottura, Bruce Chappell and two anonymous reviewers which greatly improved this manuscript. Microprobe analyses were performed at Oviedo University (Spain) kindly provided by L. G. Corretge. We thank Olga Fernández, Mayte Larrea and Maribel Sevillano for their collaboration in sample preparation and in ICP spectrometry. This work is financially supported by a CICYT (PB88-0117) project of the Ministerio de Educación y Ciencia and by a FPI-MEC grant to one of the authors (LB).

\section{References}

Andonaegui, P. 1990. Geoquímica y geocronología de los granitoides del sur de Toledo. Tesis doctoral, Universidad Complutense de Madrid, Spain.

Arzi, A. A. 1978. Critical phenomena in the rheology of partially melted rocks. TECTONOPHYSICS 44, 173-89.

Barbero, L. \& Villaseca, C. 1988. Gabros coroníticos en el macizo cristalino de Toledo. GEOGACETA 5, 67-9.

Barbero, L., Villaseca, C. \& Andonaegui, P. 1990. On the origin of the gabbro-tonalite-monzogranite association from Toledo area (Hercynian Iberian belt). SCHWEIZ MINERAL PETROGR MITT 7, 209-21.

Barbey, P., Bertrand, J. M., Angoua, S. \& Dautei, D. 1989. Petrology and $\mathrm{U} / \mathrm{Pb}$ chronology of the Telohat migmatites (Aleksod, Central Hoggar). CONTRIB MINERAL PETROL
101, 207-19.

Barbey, P., Macaudiere, J. \& Uzenti, J. P. 1990. High-pressure dehydration melting of metapelites: evidence from migmatites of Yaoundí (Cameroon). J PETROL 31, 401-28.

Bohlen, J. R. \& Liotta, J. J. (1986). A barometer for garnet amphibolites and garnet granulites. J PETROL 27, 1024-34.

Bowden, P., Batchelor, R. A., Chappell, B. W., Didier, J. \& Lameyre, J. 1984. Petrological, geochemical and source criteria for the classification of granitic rocks: a discussion. PHYS EARTH PLANET INTERIORS 35, 1-11.

Brandebourger, E. 1984. Les granitoides hercyniens tardifs de la Sierra de Guadarrama (Système Central, Espagne). Pétrographie et geochimie, These 3eme Cycle, CNRS, France.

Brändle, J. L. \& Cerqueira, I. 1972. Determinación de elementos menores en rocas silicatadas por fluorescencia de rayos X. ESTUD GEOL 28, 445-51.

Casillas, R. 1989. Las asociaciones plutónicas tardihercínicas del sector occidental de la Sierra de Guadarrama-Sistema Central Español, (Las Navas del Marqués-San Martin de Valdeiglesias). Petrología, geoquímica, génesis y evolución. Tesis Doctoral, Universidad Complutense de Madrid, Spain.

Casquet, C., Fuster, J. M., González Casado, J. M., Peinado, M. \& Villaseca, C. 1988. Extensional tectonics and granite emplacement in the Spanish Central System. A discussion. EUROPEAN SCI FOUND (SPEC VOL), PROC 5th WORK, 65-76.

Chappell, B. W., White, A. J. R. \& Wyborn, D. 1987. The importance of residual source material (restite) in granite petrogenesis. J PETROL 28, 1111-38.

Clarke, R. G. \& Lyons, J. B. 1986. Petrogenesis of the Kingsman intrusive suite: peraluminous granitoids of Western New Hampshire. J PETROL 27, 1365-93.

Debon, F. \& Le Fort, P. 1983. A chemical-mineralogical classification of common plutonic rock and associations. TRANS R SOC EDINBURGH: EARTH SCI 73, 135-49.

Del Moro, A. 1987. Sistematica $\mathrm{Rb} / \mathrm{Sr}$ di alcune magmatiti tardo-erciniche dell'area italiana. RIC SCI EDUC PERM 52, 107-32.

Dymek, F. R. 1983. Titanium, aluminium and interlayered cation substitution in biotite from high-grade gneisses, west Greenland. AM MINERAL 68, 880-99.

Ebadi, A. \& Johannes, W. 1991. Beginning of melting and composition of first melts in the system Qz-Ab-Or- $\mathrm{H}_{2} \mathrm{O}-$ $\mathrm{CO}_{2}$. CONTRIB MINERAL PETROL 106, 286-95.

Ferry, J. M. \& Spear, F. S. 1978. Experimental calibration of the partitioning of $\mathrm{Fe}$ and $\mathrm{Mg}$ between garnet and biotite. CONTRIB MINERAL PETROL 66, 113-7.

Flood, R. H. \& Shaw, S. E. 1975. A cordierite-bearing granite suite from the New England batholith. N.S.W. Australia. CONTRIB MINERAL PETROL 52, 157-64.

Frost, B. R. \& Chacko, T. 1989. The granulite uncertainty principle: limitations on thermobarometry in granulites. J GEOL 97, 435-50.

Ganguly, J. \& Saxena, S. K. 1984. Mixing properties of aluminosilicate garnets: constrains for natural and experimental data and application to geothermo-barometry. AM MINERAL 69, 88-97.

Ghent, E. D. \& Stout, M. Z. 1984. TiO 2 activity in metamorphosed pelitic and basic rocks: principles and applications to metamorphism in southeastern Canadian Cordillera. CONTRIB MINERAL PETR OL 86, 248-55.

Grapes, R. H. 1985. Melting and thermal reconstruction of pelitic xenolith, Wehr volcano, east Eifel, west Germany. J PETROL 27, 343-96.

Green, D. \& Ringwood, A. 1967. An experimental investigation of the gabbro to eclogite transformation and its petrological applications. GEOCHIM COSMOCHIM ACTA 31, 767-833.

Gromet, L. P., Dymek, R. F., Haskin, L. A. \& Korotev, R. L. 1984. The "North American Shale composite": its compilation, major and trace element characteristics. GEOCHIM COSMOCHIM ACTA 48, 2469-82.

Hodges, K. V. \& Spear, F. S. 1982. Geothermometry, geobarometry and the $\mathrm{Al}_{2} \mathrm{O}_{3}$ triple point at $\mathrm{Mt}$ Moosilauke, New Hampshire. AM MINERAL 67, 1118-34.

Holdaway, M. J. \& Lee, S. N. 1977. Fe-Mg cordierite stability in high-grade pelitic rocks based on experimental, theoretical and natural observations. CONTRIB MINERAL PETROL 63, 175-98.

Ibarguchi, J. I. G. \& Martínez, F. J. 1982. Petrology of garnet-cordierite-sillimanite gneisses from the El Tormes thermal Dome, Iberian Hercynian foldbelt (W Spain). CONTRIB MINERAL PETROL 80, 14-24. 
Jones, K. A. \& Brown, M. 1990. High-temperature 'clockwise' P-T paths and melting in the development of regional migmatites: an example from southern Brittany, France. J MET GEOL 8, 551-78.

Julivert, M., Fontboté, J. M., Ribeiro, A. \& Conde, L. E. 1974. Memoria explicativa del mapa tectónico de la Península Ibérica y Baleares. Escala $1: 100,000$. I.G.M.E., Madrid, Spain.

Lavrenteva, E. V. \& Perchuck, L. L. 1981. Cordierite-garnet thermometer. A collection of theses. ACAD SCI USSR 259, $607-700$.

Le Breton, N. \& Thompson, A. B. 1988. Fluid-absent (dehydration) melting of biotite in metapelites in the early stages of crustal anatexis. CONTRIB MINERAL PETROL 99, 226-37.

Martín Escorza, C. \& López Martínez, J. 1978. Análisis mesoestructural en la Unidad Migmatítica de Toledo. ESTUD GEOL 34, 34-43.

Masuda, A., Nakamura, N. \& Tanaka, T. 1973. Fine structures of mutual normalized rare earth patterns of chondrites. GEOCHIM COSMOCHIM ACTA 37, 239-48.

McRae, N. D. \& Nesbitt, H. W. 1980. Partial melting of common metasedimentary rocks: a mass balance approach. CONTRIB MINERAL PETROL 75, 21-6.

Miller, C. F. 1985. Are strongly peraluminous magmas derived from pelitic sedimentary sources? J GEOL 93, 673-89.

Miller, C. F., Watson, E. B. \& Harrison, T. M. 1988. Perspectives on the source, segregation and transport of granitoid magmas. TRANS R SOC EDINBURGH EARTH SCI 79, 135-56.

Minster, F. J. \& Allègre, C. J. 1977. Systematic use of trace elements in igneous processes. Part I: Fractional crystallization processes in volcanic suites. CONTRIB MINERAL PETROL 60, 57-75.

Moller, P. \& Muecke, G. K. 1984. Significance of europium anomalies in silicate melts and crystal melt equilibria: a re-evaluation. CONTRIB MINERAL PETROL 87, 242-50.

Patin̄o, A. \& Johnston, A. 1991. Phase equilibria and melt productivity in the pelitic system: implications for the origin of peraluminous granitoids and aluminous granulites. CONTRIB MINERAL PETROL 107, 202-18.

Rottura, A., Bargossi, G. M., Caironi, V., D’Amico, C. \& Maccarrone, E. 1989. Petrology and geochemistry of late-Hercynian granites from the Western Central System of the Iberian Massif. EUR J MINER 1, 667-83.

Rottura, A., Bargossi, G. M., Caironi, V., Del Moro, A., Maccarrone, E., Macera, P., Paglionico, A. Petrini, R. Piccarreta, G. \& Poli, G. 1990. Petrogenesis of contrasting Hercynian granitoids from the Calabrian Arc, southern Italy. LITHOS 24, 97-119.

Sawyer, E. W. 1987. The role of partial melting and fractional crystallisation in determining discordant migmatite leucosome compositions. J PETROL 28, 445-73.

Sengupta, P., Dasgupta, S. K., Bhattacharya, P. K. \& Mukherjee, M. 1990. An orthopyroxene-biotite geothermometer and its application in crustal granulites and mantle derived rocks. J MET GEOL 8, 191-8.

Speer, J. A. 1981. Petrology of cordierite- and almandine-bearing granitoid plutons of the southern Appalachian piedmont, U.S.A. CAN MINERAL 19, 35-46.

Streckeisen, A. 1976. To each plutonic rock its proper name. EARTH SCI REV 12, 1-13.

Thompson, R. N., Morrison, M. A., Hendry, G. L. \& Parry, S. J 1984. An assessment on the relative roles of crust and mantle magma genesis: an elemental approach. PHILOS TRANS R SOC LONDON A310, 549-90.

Van der Molen, I. \& Paterson, M. S. 1979. Experimental deformation of partially-melted granite. CONTRIB MINERAL PETROL 70, 299-318.

Vialette, Y., Casquet, C., Fúster, J. M., Ibarrola, E., Navidad, M., Peinado, M. \& Villaseca, C. 1987. Geochronological study of orthogneisses from the Sierra de Guadarrama (Spanish Central System). N JARB MINER MH JG H10, 465-79.

Vielzeuf, D. 1983. The spinel and quartz associations in high grade xenoliths from Tallante (SE Spain) and their potential use in geothermometry and barometry. CONTRIB MINERAL PETROL 82, 301-11.

Vielzeuf, D., Clemens, J. D., Pin, C. \& Moinet, E. 1990. Granites, granulites and crustal evolution. In Vielzeuf, D. \& Vidal, Ph. (eds) Granulites and crustal evolution. NATO ASI SCI SER C 311, 59-85.

Vielzeuf, D. \& Holloway, J. R. 1988. Experimental determination of the fluid-absent melting relations in the pelitic system. Consequences for crustal differentiation. CONTRIB MINERAL PETROL 98, 257-76.

Villaseca, C. 1983. Evolución metamórfica del sector centroseptentrional de la Sierra de Guadarrama. Tesis Doctoral 216/84, Universidad Complutense de Madrid, Spain.

Villaseca, C. \& Barbero, L. (in press). Los granates de rocas metapelíticas de la región central española: implicaciones en el origen de granates en granitoides. GEOGACETA (in press).

Vry, J. K., Brown, E. B. \& Valley, J. W. 1990. Cordierite volatile content and the role of $\mathrm{CO}_{2}$ in high-grade metamorphism. AM MINERAL 75, 71-88.

Watson, E. B. 1987. The role of accessory minerals in granitoid geochemistry. 1ST HUTTON SYMP ABSTR, 19-21.

Wells, P. R. A. 1977. Pyroxene thermometry in simple and complex systems. CONTRIB MINERAL PETROL 62, 129-39.

Whalen, J. B. \& Chappell, B. W. 1988. Opaque mineralogy and mafic mineral chemistry of I- and S-type granites of the Lachlan fold belt, southern Australia. AM MINERAL 73, 281-96.

White, A. J. R. \& Chappell, B. W. 1987. Some supracrustal (S-type) granites of the Lachlan Fold Belt. TRANS R SOC EDINBURGH EARTH SCI 79, 169-81.

Wickham, S. M. 1987a. Crustal anatexis and granite petrogenesis during low pressure regional metamorphism in the Trois Seigneurs massif, Pyrenees, France. J PETROL 28, 127-69.

Wickham, S. M. 1987b. The segregation and emplacement of granitic magmas. J GEOL SOC LONDON 144, 281-97.

Wildberg, H. G. H., Bischoff, L. \& Baumann, A. 1989. U-Pb ages of zircons from meta-igneous and metasedimentary rocks of the Sierra de Guadarrama: implications for the Central Iberian crustal evolution. CONTRIB MINERAL PETROL 103, 253-62.

L. BARBERO and C. VIllaseCA, Dpto. Petrología y Geoquímica, Fac. C.C. Geológicas, Universidad

Complutense, 28040 Madrid, Spain. 